\title{
CHEMOSPHERE
}

\section{Evaluation of soil temperature effect on herbicide leaching potential into groundwater in the Brazilian Cerrado}

\author{
Lourival Costa Paraíba ${ }^{a, *}$, Antonio Luiz Cerdeira ${ }^{a}$, Enio Fraga da Silva ${ }^{b}$, \\ João Souza Martins ${ }^{\mathrm{b}}$, Heitor Luiz da Costa Coutinho ${ }^{\mathrm{b}}$ \\ a Embrapa Meio Ambiente, Embrapa Environment, Jaguariúna, CP 69, 13820-000 SP, Brazil

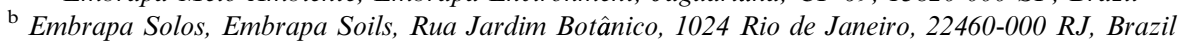

Received 22 January 2003; received in revised form 4 June 2003; accepted 11 June 2003

\begin{abstract}
The effect of annual variations in the daily average soil temperatures, at different depths, on the calculation of pesticide leaching potential indices is presented. This index can be applied to assess the risk of groundwater contamination by a pesticide. It considers the effects of water table depth, daily recharge net rate, pesticide sorption coefficient, and degradation rate of the pesticide in the soil. The leaching potential index is frequently used as a screening indicator in pesticide groundwater contamination studies, and the temperature effect involved in its calculation is usually not considered. It is well known that soil temperature affects pesticide degradation rates, air-water partition coefficient, and water-soil partition coefficient. These three parameters are components of the attenuation and retardation factors, as well as the leaching potential index, and contribute to determine pesticide behavior in the environment. The Arrhenius, van't Hoff, and Clausius-Clapeyron equations were used in this work to estimate the soil temperature effect on pesticide degradation rate, air-water partition coefficient, and water-soil partition coefficient, respectively. The relationship between leaching potential index and soil temperature at different depths is presented and aids in the understanding of how potential pesticide groundwater contamination varies on different climatic conditions. Numerical results will be presented for 31 herbicides known to be used in corn and soybean crops grown on the municipality of São Gabriel do Oeste, Mato Grosso do Sul State, Brazil.
\end{abstract}

(c) 2003 Elsevier Ltd. All rights reserved.

Keywords: Herbicide; Groundwater; Leaching index; Temperature; Cerrado

\section{Introduction}

The protection and conservation of the quality of groundwater resources are an essential part of a sus-

\footnotetext{
${ }^{*}$ Corre sponding author. Tel.: +55-19-386-78767; fax: +55 19-38678740.

E-mail addresses: lourival@enpma.embrapa.br (L.C. Paraíba), cerdeira@cnpma.embrapa.br (A.L. Cerdeira), enio@, cnps.embrapa.br (E.F. da Silva), martins@cnps.embrapa.br (J.S. Martins), heitor@cnps.embrapa.br (H.L. da Costa Coutinho).
}

tainable agricultural production systems. Thus, the impact of pesticides on groundwater quality has been the subject of scientific and public health concerns worldwide, especially in areas where groundwater is mainly used for human consumption. Only in the last decade has pesticide leaching to groundwater been considered an important nonpoint source of agricultural pollution. Over a decade ago, it was assumed that pesticides would not leach to underlying groundwater (Bouwer, 1990). However, groundwater quality surveys conducted during this decade have revealed contamination of some USA aquifers with both inorganic and organic compounds, several of them are pesticides (Williams et al., 1988). 
Large-scale high-input food production, based on mechanized monocultures in industrial farming systems, strongly depend on the use of pesticides, with herbicides representing about $50 \%$ of all pesticides used in many countries (Sattin et al., 1995). The intensive use of herbicides in agriculture, and the high persistence of many of them, have required a rigorous control of possible environmental contamination, especially of groundwater and other drinking water sources. Corn and soybean cropping systems represent about $30 \%$ of the total world market share of herbicides (Sattin et al., 1995), and have been intensified for the last 20 years in the Brazilian Cerrado region (Goedert, 1983), with more than 30 million hectares being used for cereal, corn, and soybean production (Resck, 1998). Herbicides represent $56 \%$ of the total dollar value of the pesticide business in Brazil (Oliveira et al., 2001).

The municipality of São Gabriel do Oeste, located in the Midwest of Brazil, Mato Grosso do Sul State, is an important corn and soybean producing region, with an intensive herbicide utilization. This region is also an important recharge area for groundwater supply of the Guarani aquifer, which spreads under the area of eight Brazilian states, as well as parts of Argentina, Uruguay, and Paraguay, with a total area of approximately $1200000 \mathrm{~km}^{2}$. The problem has worsened, given the high permeability of some soils occurring in the area, and the common usage of products with high mobility, which constitute factors that elevate the potential of risk of undesirable contamination of the aquifer. This risk of negative environmental impacts become even greater, considering that $100 \%$ of the water for urban provisioning in this region is coming from that aquifer. This region has been chosen, as a research site, because of its characteristics in order to study the movement of corn and soybean herbicides through the soil profile.

Intensive laboratory and field studies are required to identify and characterize the predominant physical and chemical processes that describe the transport, persistence and fate of a particular pesticide at a determined site of application. Risk analysis of groundwater pesticide contamination involves the assessment of the pesticide properties, soil characteristics, and weather conditions. Laabs et al. (2002), in a pilot study of leaching and degradation of corn and soybean pesticides in an Oxisol of the Brazilian Cerrados, have shown that the overall pesticide half-life in the studied soil conditions differs from temperate weather conditions, and leaching studies revealed low or moderate mobility. They reported a faster degradation rate of pesticides in comparison to the rate found in temperate climates, due to enheightened microbial populations and activities under the modified environmental conditions as a result of higher temperature in the soil. Thus, the objective of this study is to consider soil temperature effect, herbicide characteristics and soil properties to classify 31 herbi- cides used in the corn and soybean cropping region of São Gabriel do Oeste into leachability classes of the potential groundwater contamination.

\section{Methods}

Pesticide leaching indices are frequently used by government agencies and private corporation to rank groundwater contamination risk because the transport and degradation of organic compounds is too complex involving physical, chemical, and biological processes (Gustafson, 1994; Boesten, 2000). The soil temperature decreases with depth during daytime in the summer; and sorption, physical, and microbial degradation processes are known to be affected by temperature (Walker and Barnes, 1981; Hulscher and Cornelissen, 1996). Walker (1974) considered the transformation and degradation within the soil as the only processes involved in pesticide loss. Assuming that they are controlled by soil temperature and moisture content, he used an Arrhenius type equation to describe the pesticide transformation rate. The half-life of the herbicide atrazine in soil is temperature dependent (Rattanagreetakul et al., 1991). Brücher and Bergström (1997), studying the herbicide linuron sorption to three different agricultural soils and having observed that the partition coefficient changed by a factor up to 1.5 at low linuron concentrations. They also observed that the isotherms increased with decreasing temperature in sandy soils, as opposed to clay soils, where the isotherms increased along with soil temperature. Hulscher and Cornelissen (1996) presented a review enhancing the importance of temperature on the sorption and sorption kinetics of organic compounds.

The outputs of potential groundwater pesticide contamination simulation models can differ if the effects of soil temperature on the degradation rate, air-water partition, and water-soil sorption processes are not considered (Wu and Nofziger, 1999; Paraíba and Spadotto, 2002). Thus, we propose a modified version of a leaching potential index (LPI) that can estimate the potential pesticide leaching taking into consideration the periodical variation of the average daily soil temperatures on pesticide degradation rates, soil sorption coefficient, and dimensionless pesticide partition air-water coefficient.

\subsection{Leaching potential index}

In order to study the effect of the soil profile mean temperature on the leaching potential of any pesticide in a specified area, the methodology proposed by Meeks and Dean (1990) was adapted. Meeks and Dean (1990) have proposed a LPI to evaluate the risk of groundwater contamination by a pesticide or organic chemical adding 
the effects of depth of water table, net rate of daily recharge, pesticide sorption coefficient, and degradation rate of the pesticide in the soil. By introducing minor modifications to the LPI, Schlosser et al. (2002) were successful in evaluating the vulnerability of the Weld County, Colorado, aquifer. Schlosser and McCray (2002) have analyzed the sensibility of the LPI to the physical and chemical parameters of the pesticides and the soil hydrologic characteristics. Bari and Anwar (1998) have used LPI to evaluate groundwater vulnerability to pesticide leaching, prioritizing monitoring sites in northwest Bangladesh. Pickus and Hewitt (1992) have developed the Pesticide User Management Planning System (PUMPS) to assist natural resource managers in understanding the effects of pesticides on groundwater. PUMPS uses geographical information system (GIS) and LPI to assess groundwater sensitivity to pesticides, and was first used in Delaware, USA. Soil temperature effect was not considered in these studies.

Dispersion-advection equations describe the mass movement of a pesticide leaching into the soil. If hydrodynamic dispersion is neglected, by assuming a stead state flow of the soil solution, the result produced by this simplified equation is a practical expression that estimates the pesticide mass remaining at a $z$ depth of the soil and at $t$ time. This simplified solution is known as attenuation factor, AF (Rao et al., 1985) and it can be expressed by the equation

$\operatorname{AF}(z)=\exp \left(\frac{-k z R_{\mathrm{f}} \theta_{\mathrm{fc}}}{J_{\mathrm{w}}}\right)$

where $\operatorname{AF}(z)$ (dimensionless) is the attenuation factor or the remaining pesticide is relative mass in the depth soil $z$ $(\mathrm{m}), k\left(\mathrm{day}^{-1}\right)$ is the soil pesticide degradation rate estimated by $k=\ln (2.0) / t_{1 / 2}$, where $t_{1 / 2}$ (day) is the pesticide half-life in the soil, $R_{\mathrm{f}}$ (dimensionless) is the retardation factor, $\theta_{\mathrm{fc}}$ is the soil volumetric water content at field capacity, and $J_{\mathrm{w}}\left(\mathrm{m} \mathrm{day}^{-1}\right)$ is the water daily net recharge of the specific soil area. The retardation factor $\left(R_{\mathrm{f}}\right)$ in Eq. (1) is given by

$R_{\mathrm{f}}=1+\frac{\rho f_{\mathrm{oc}} K_{\mathrm{oc}}}{\theta_{\mathrm{fc}}}+\frac{\delta H}{\theta_{\mathrm{fc}}}$

where $\rho\left(\mathrm{kg} \mathrm{m}^{-3}\right)$ is the soil density, $K_{\mathrm{oc}}\left(\mathrm{m}^{3} \mathrm{~kg}^{-1}\right)$ is the pesticide soil organic carbon partition coefficient, $f_{\mathrm{oc}}$ is the volumetric organic carbon content of the soil, $\delta$ is the volumetric air content when at field capacity, and $H$ (dimensionless Henry's constant) is the pesticide airwater partition coefficient. Meeks and Dean (1990) have used the inverse of the exponential argument of the Eq. (1) for a specific site and constant daily soil temperature to produce the LPI defined as

$$
\mathrm{LPI}=\frac{1000 J_{\mathrm{w}}}{k z R_{\mathrm{f}} \theta_{\mathrm{fc}}}
$$

where the factor 1000 was used to convert the quotient given by Eq. (3) to numerical values of practical use. Meeks and Dean (1990) have suggested five leachability classes to classify the leaching potential of a pesticide, which are very low, low, moderate, high, and very high. The variations produced by Eq. (3) were associated to numerical intervals $[0,24],(24,49],(49,74],(74,89]$, $(89,+\infty)$, respectively. Thus, LPI can be used as a groundwater vulnerability index to pesticide contamination according to the leaching potential of each compound.

\subsection{Temperature leaching potential index}

It is possible to use the effect of soil temperature as an attenuation factor, and calculate the remaining mass of a pesticide throughout a soil profile, by a pesticide degradation kinetics Arrhenius equation. It is also possible to calculate the retardation factor by adding the effect of soil temperature on the pesticide soil sorption coefficient, of Clausius-Clapeyron equation, and airwater pesticide partition coefficient, given by van't Hoff equation. The proposed adaptation is similar to the one suggested by Paraíba and Spadotto (2002) which calculates the attenuation and retardation factors, by adding the soil temperature effect. Since the pesticide degradation rate and retardation factor are included, in the LPI value the risk indicator of pesticide contamination of the groundwater can not neglect soil temperature, particularly in tropical areas. Soil temperature was included in the equation to calculate the LPI. It is necessary to adopt a function that describes daily average temperature at different depths. The following sinusoidal function expression describes the annual variation of daily average soil temperature at different depths

$T(z, t)=T_{\mathrm{a}}+A_{0} \exp (-z / d) \sin \left(\varpi t-z / d-\varphi_{0}\right)+273$

where $T=T(z, t)(\mathrm{K})$ is the daily average soil temperature, $t$ is the time (day), $T_{\mathrm{a}}=\left(T_{\max }+T_{\min }\right) / 2$ is the annual average surface temperature of the soil $\left({ }^{\circ} \mathrm{C}\right)$, $A_{0}=\left(T_{\max }-T_{\min }\right)$ is the annual amplitude between maximum $\left(T_{\max }\right)$ and minimum $\left(T_{\min }\right)$ annual surface soil temperature in ${ }^{\circ} \mathrm{C}$, respectively. The parameter $d$, in Eq. (4), designates the thermal damping depth, which characterizes attenuation of the diurnal temperature wave along with soil depth. This value can be calculated by the formula $d=\sqrt{2 \tau /\left(C_{\mathrm{h}} \varpi\right)}$, where $\tau$ $\left(\mathrm{kJ} \mathrm{mol}^{-1} \mathrm{~K}^{-1} \mathrm{~m}^{2} \mathrm{day}^{-1}\right)$ is the soil thermal conductivity, $C_{\mathrm{h}}\left(\mathrm{kJ} \mathrm{mol}^{-1} \mathrm{~K}^{-1}\right)$ is the heat soil volumetric capacity, and $\varpi=2 \pi / 365\left(\right.$ day $\left.^{-1}\right)$ is the radial frequency. $\varphi_{0}=$ $\pi / 2+\varpi t_{0}$ (dimensionless) is the phase constant, and $t_{0}$ (day) is the time lag from the arbitrary starting date to the occurrence of the minimum annual temperature 
(Hillel, 1982; Campbell, 1985; Jury et al., 1992; Wu and Nofziger, 1999).

The relationship between the soil pesticide degradation rate and the soil temperature can be described by the Arrhenius equation given by

$k(z, t)=\left(\frac{\ln (2.0)}{t_{1 / 2}}\right) \exp \left(\frac{E_{\mathrm{a}}}{R}\left(\frac{1}{T_{\mathrm{r}}+273}-\frac{1}{T(z, t)}\right)\right)$

where $T_{\mathrm{r}}\left(=20\right.$ or $\left.25^{\circ} \mathrm{C}\right)$ is the reference temperature, $E_{\mathrm{a}}$ $\left(\mathrm{kJ} \mathrm{mol}^{-1}\right)$ is the pesticide degradation activation energy and $R=8.314 \times 10^{-3} \mathrm{~kJ} \mathrm{~mol}^{-1} \mathrm{~K}^{-1}$ is the gas constant (Keen and Spain, 1992; Rocha and Walker, 1995).

Based on fundamental thermodynamic concepts, the Clausius-Clapeyron equation can be used to determine soil temperature and air-water pesticide partition coefficient (Sagebiel et al., 1992; Bacci, 1994; Rice et al., 1997), using the following equation

$$
\begin{aligned}
H(z, t)= & \left(\frac{P_{\mathrm{m}} P_{\mathrm{v}}^{T_{\mathrm{r}}}}{S R\left(T_{\mathrm{r}}+273\right)}\right) \\
& \times \exp \left(\frac{\Delta H_{\mathrm{v}}}{R}\left(\frac{1}{T_{\mathrm{r}}+273}-\frac{1}{T(z, t)}\right)\right)
\end{aligned}
$$

where $P_{\mathrm{m}}\left(\mathrm{g} \mathrm{mol}^{-1}\right)$ is the pesticide molecular weight, $P_{\mathrm{v}}^{T_{\mathrm{r}}}$ $(\mathrm{Pa})$ is the pesticide vapor pressure at the reference temperature, $S\left(\mathrm{~g} \mathrm{~m}^{-3}\right)$ is the pesticide aqueous solubility, and $\Delta H_{\mathrm{v}}\left(\mathrm{kJ} \mathrm{mol}^{-1}\right)$ is the enthalpy of volatilization. The coefficient $P_{\mathrm{m}} P_{\mathrm{v}}^{T_{\mathrm{r}}} /\left(S R\left(T_{\mathrm{r}}+273\right)\right)$ in Eq. (6) is the dimensionless Henry's constant or pesticide air-water partition coefficient.

Thus, pesticide air-water partition coefficient can be determined using depth $z$ at time $t$ in the function (6). For each depth $z$ and each time $t$ the function $H=H(z, t)$ is a thermodynamic balance between soil air and soil water. It is expected that this balance exhibits dependence with soil temperature. According to Kavanaugh and Trussel (1980), Schwarzenbach et al. (1993), and Rice et al. (1997), the pesticide air-water partition coefficient increases a range factor of 1.2-1.8 for each Celsius degree of temperature increase, in a range of 10 $20{ }^{\circ} \mathrm{C}$.

The calculation of the pesticide water-soil partition coefficient, or pesticide sorption coefficient, $K_{\mathrm{D}}=K_{\mathrm{D}}(z, t)$ can be estimated for different soil temperatures using the van't Hoff equation given by

$K_{\mathrm{D}}(z, t)=\left(f_{\mathrm{oc}} K_{\mathrm{oc}}\right) \exp \left(\frac{\Delta H_{\mathrm{a}}}{R}\left(\frac{1}{T_{\mathrm{r}}+273}-\frac{1}{T(z, t)}\right)\right)$

where $\Delta H_{\mathrm{a}}\left(\mathrm{kJ} \mathrm{mol}^{-1}\right)$ is the sorption enthalpy. The coefficient $f_{\mathrm{oc}} K_{\mathrm{oc}}$ in Eq. (7) is the pesticide sorption coefficient or pesticide water-soil partition coefficient, at the reference temperature $T_{\mathrm{r}}$.
When $\Delta H_{\mathrm{v}}$ and $\Delta H_{\mathrm{a}}$ are not known, or when they are not available in the literature, one can use the Goss and Schwarzenbach (1999) relationship to estimate those values. Such empirical relations are given, respectively, by

$$
\begin{aligned}
\Delta H_{\mathrm{v}} & =-3.8 \ln \left(P_{\mathrm{v}}^{20}\right)+70.0 \\
\Delta H_{\mathrm{a}} & =-4.17 \ln \left(\frac{f_{\text {oc }} K_{\mathrm{oc}}}{1.0 \times 10^{3} \mathrm{SSA}}\right)-88.1
\end{aligned}
$$

where $P_{\mathrm{v}}^{20}(\mathrm{~Pa})$ is the pesticide vapor pressure at the reference temperature $T_{\mathrm{r}}=20{ }^{\circ} \mathrm{C}$, and SSA $\left(\mathrm{m}^{2} \mathrm{~g}^{-1}\right)$ is the soil specific surface area. The specific surface is estimated as follows (Pionke and De Angelis, 1972)

$\mathrm{SSA}=100.0\left(100.0 f_{\mathrm{oc}}+2.0 f_{\mathrm{cl}}+0.4 f_{\mathrm{st}}+0.005 f_{\mathrm{sd}}\right)$

where $f_{\mathrm{cl}}$ is the soil clay volumetric fraction, $f_{\mathrm{st}}$ is the soil silt volumetric fraction and $f_{\text {sd }}$ is the soil sand volumetric fraction. In this simulation, the Goss and Schwarzenbach (1999) equation was used to estimate $\Delta H_{\mathrm{v}}$ and $\Delta H_{\mathrm{a}}$.

Soil temperature effect was introduced in the retardation factor and LPI, supposing that soil profile is layered. Depth $L$ meters is layered in $n$ layers of thickness $\Delta L$, that is, $\Delta L=L / n$. The value of $l_{n+1}=l_{i}+\Delta L$ (m) represents the soil depth $i \in\{0,1,2, \ldots, n-1\}$, with $l_{0}=0$ representing the soil surface and $l_{n}=L$. In each layer of soil of thickness $\left[l_{i}, l_{i+1}\right]$ the pesticide is degraded according to Arrhenius equation. For each soil layer $\left[l_{i} l_{i+1}\right]$, where $i \in\{0,1,2, \ldots, n-1\}, \quad z \in\left[l_{i}, l_{i+1}\right], 0 \leqslant$ $t \leqslant t_{\mathrm{h}}$, and $t_{\mathrm{h}}$ (day) is the maximum number of days of the leaching simulation, several values of retardation factor is given by

$R_{\mathrm{f}}(z, t)=1+\frac{\rho K_{\mathrm{D}}(z, t)}{\theta_{\mathrm{fc}}^{z}}+\frac{\delta H(z, t)}{\theta_{\mathrm{fc}}^{z}}$

where $\theta_{\mathrm{fc}}^{z}$ is the volumetric water content at field capacity in the soil depth $z$. Minor modifications in LPI, considering soil temperature effects, were made as follows:

$\mathrm{TLPI}=\frac{1000 J_{\mathrm{w}}}{k\left(L, t_{\mathrm{h}}\right) L R_{\mathrm{f}}\left(L, t_{\mathrm{h}}\right) \theta_{\mathrm{fc}}^{L}}$

where TLPI is the temperature leaching potential for soil depth $L$ and after $t_{\mathrm{h}}$ days of pesticide application, $\theta_{\mathrm{fc}}^{L}$ is the volumetric water content at field capacity in soil depth $L$. The values $k\left(L, t_{\mathrm{h}}\right)$ and $R_{\mathrm{f}}\left(L, t_{\mathrm{h}}\right)$ in expression (12) are, respectively, the pesticide degradation rate and the retardation factor calculated by Eqs. (5) and (11) at depth $z=L$ and time $\left(t=t_{\mathrm{h}}\right)$. Thus, defining a simulation time horizon $t_{\mathrm{h}}$ in days, and soil depth $L$ in meters, it is possible to estimate the risk of groundwater pesticide contamination at a specific site by the proposed equation (12). Thus keeping the same risk classification parameters and numerical intervals of LPI, suggested by Meeks and Dean (1990), it is possible to determine levels 
of potential contamination or leachability classes of different pesticides groups using TLPI equation. This novel approach takes into consideration the influence of soil temperature on the pesticide half-life, pesticide sorption coefficient, and pesticide air-water partition coefficient. Therefore, the TLPI index corresponds to the LPI index when the soil temperature effect is also considered factor in this equation.

\subsection{Classification in leachability class}

The 31 main herbicides used in corn and soybean crops in the Cerrado region of São Gabriel do Oeste were selected to classify these compounds by their potential to contaminate the groundwater, after temperature effect was included into the potential index (TLPI). According to the pesticide database compiled by Hornsby et al. (1996), the necessary physical and chemical data used to calculate the risk by TLPI are presented in Table 1. Since these physical and chemical characteristics were obtained in laboratory experiments at 20 or $25^{\circ} \mathrm{C}$ average temperature of, for the numerical calculations of the TLPI index the value $T_{\mathrm{r}}=20^{\circ} \mathrm{C}$, as the reference temperature.

For all herbicides, the Arrhenius activation energy constant $E_{\mathrm{a}}$ used in the expression (5) was the $E_{\mathrm{a}}=56$ $\mathrm{kJ} \mathrm{mol}^{-1}$. This value is in agreement with the Arrhenius activation energy obtained by Veeh et al. (1996) for herbicide 2,4-D, with the average values obtained by Baer and Calvet (1999) for herbicides atrazine, sulcotrione, simazine, and diuron; and the average values obtained for Gómez de Barreda (1999) for herbicides molinate, terbuthylazine, terbacil, and thiobencarb; in eight different soil types of the Valencia Community, Spain. For each pesticide, the enthalpy of volatilization $\Delta H_{\mathrm{v}}$ was estimated by Eq. (8), and used separately to calculate the TLPI values. Those values were used to calculate the average value of the $\Delta H_{\mathrm{v}}=106 \mathrm{~kJ} \mathrm{~mol}^{-1}$. This value is in agreement with enthalpy of volatilization predicted by Nirmalakhandan et al. (1997) for several organic compounds. We have taken two representative soil sample from studied site, each having contrasting

Table 1

Properties of the main herbicides used in the area (Hornsby et al., 1996; Tomlin, 2000)

\begin{tabular}{|c|c|c|c|c|c|}
\hline Herbicide & $P_{\mathrm{m}}\left(\mathrm{g} \mathrm{mol}^{-1}\right)$ & $P_{\mathrm{v}}(\mathrm{Pa})$ & $S\left(\mathrm{~g} \mathrm{~m}^{-3}\right)$ & $K_{\mathrm{oc}}\left(\mathrm{m}^{3} \mathrm{~kg}^{-1}\right)$ & $t_{1 / 2}$ (day) \\
\hline $2,4-\mathrm{D}$ & 221.0 & $1.86 \mathrm{E}-02$ & 20031.00 & $2.00 \mathrm{E}-02$ & 10 \\
\hline Acifluorfen-sodium & 383.6 & $1.00 \mathrm{E}-05$ & 62.07 & $1.13 \mathrm{E}-01$ & 14 \\
\hline Alachlor & 269.8 & $2.00 \mathrm{E}-03$ & 170.31 & $1.50 \mathrm{E}-01$ & 15 \\
\hline Atrazine & 215.7 & $3.85 \mathrm{E}-05$ & 33.00 & $1.00 \mathrm{E}-01$ & 77 \\
\hline Bentazone & 240.3 & $1.70 \mathrm{E}-04$ & 570.00 & $3.40 \mathrm{E}-02$ & 20 \\
\hline Butroxydim & 399.5 & $1.00 \mathrm{E}-05$ & 6.90 & $4.30 \mathrm{E}-02$ & 9 \\
\hline Chlorimuron-ethyl & 414.8 & $4.90 \mathrm{E}-07$ & 1200.00 & $1.10 \mathrm{E}-01$ & 40 \\
\hline Clomazone & 239.0 & $1.92 \mathrm{E}-03$ & 1100.00 & $3.00 \mathrm{E}-01$ & 30 \\
\hline Cyanazine & 240.0 & $2.13 \mathrm{E}-07$ & 171.00 & $1.90 \mathrm{E}-01$ & 14 \\
\hline Diclosulam & 406.2 & $6.70 \mathrm{E}-13$ & 6.32 & $1.10 \mathrm{E}-02$ & 65 \\
\hline Dimethenamid & 275.8 & $3.67 \mathrm{E}-02$ & 1.20 & $9.40 \mathrm{E}-02$ & 43 \\
\hline Diquat & 344.0 & $1.00 \mathrm{E}-05$ & 700.00 & $1.00 \mathrm{E}+03$ & 1000 \\
\hline Fenoxaprop & 361.8 & $5.30 \mathrm{E}-07$ & 0.70 & $3.00 \mathrm{E}-01$ & 21 \\
\hline Fluazifop-p-butyl & 383.4 & $3.33 \mathrm{E}-05$ & 1.10 & $5.70 \mathrm{E}+00$ & 15 \\
\hline Flumetsulam & 325.3 & $3.70 \mathrm{E}-10$ & 100.00 & $2.00 \mathrm{E}-03$ & 60 \\
\hline Flumiclorac-pentyl & 423.9 & $1.00 \mathrm{E}-05$ & 0.19 & $2.83 \mathrm{E}+00$ & 5 \\
\hline Fomesafen & 438.8 & $4.00 \mathrm{E}-06$ & 10.00 & $6.00 \mathrm{E}-02$ & 100 \\
\hline Haloxyfop & 361.7 & $1.33 \mathrm{E}-06$ & 1590.00 & $7.50 \mathrm{E}-02$ & 55 \\
\hline Imazaquin & 311.3 & $1.30 \mathrm{E}-05$ & 120.00 & $2.00 \mathrm{E}-02$ & 60 \\
\hline Imazethapyr & 289.3 & $1.30 \mathrm{E}-05$ & 1400.00 & $1.00 \mathrm{E}-02$ & 90 \\
\hline Lactofen & 461.8 & $9.30 \mathrm{E}-06$ & 1.00 & $1.00 \mathrm{E}+02$ & 7 \\
\hline Linuron & 249.1 & $5.10 \mathrm{E}-05$ & 63.80 & $4.00 \mathrm{E}-01$ & 60 \\
\hline Metolachlor & 283.8 & $4.20 \mathrm{E}-03$ & 488.00 & $2.00 \mathrm{E}-01$ & 90 \\
\hline Metribuzin & 214.3 & $5.80 \mathrm{E}-05$ & 1050.00 & $6.00 \mathrm{E}-02$ & 40 \\
\hline Paraquat & 257.2 & $1.00 \mathrm{E}-05$ & 620000.00 & $1.00 \mathrm{E}+04$ & 1000 \\
\hline Pendimethalin & 281.3 & $4.00 \mathrm{E}-03$ & 0.30 & $5.00 \mathrm{E}+00$ & 90 \\
\hline Picloram & 241.5 & $8.40 \mathrm{E}-05$ & 430.00 & $5.00 \mathrm{E}+00$ & 30 \\
\hline Sethoxydim & 327.5 & $1.30 \mathrm{E}-05$ & 25.00 & $1.00 \mathrm{E}-01$ & 5 \\
\hline Sulfentrazone ${ }^{a}$ & 387.2 & $1.30 \mathrm{E}-07$ & 0.11 & $4.20 \mathrm{E}-02$ & 540 \\
\hline Simazine & 201.7 & $2.94 \mathrm{E}-06$ & 6.20 & $9.50 \mathrm{E}-02$ & 60 \\
\hline Trifluralin & 335.3 & $6.10 \mathrm{E}-03$ & 0.18 & $8.00 \mathrm{E}+00$ & 60 \\
\hline
\end{tabular}

\footnotetext{
${ }^{\mathrm{a}}$ Tomlin (2000).
} 
physical properties: a Typic Orthic Neosol Quartzarenic Brazilian (TONQ) (USDA, 1999), and a Typic Distrophic Red Latossol (TDRL) (USDA, 1999), Tables 2 and 3, respectively. The soil specific surface area (SSA) in Tables 2 and 3 were estimated by Eq. (10). Using the herbicide numerical values of Table 1 and the soil numerical values of Tables 2 and 3, the heat of sorption $\Delta H_{\mathrm{a}}$ was estimated by Eq. (9). The estimated values, and their respective average values $-12.32 \mathrm{~kJ} \mathrm{~mol}^{-1}$ and $-12.75 \mathrm{~kJ} \mathrm{~mol}^{-1}$, are of the same order of magnitude of the heat of sorption, as well as of the respective average value $\left(-8 \mathrm{~kJ} \mathrm{~mol}^{-1}\right)$ of the organic micropollutants compiled by Hulscher and Cornelissen (1996).

Computations of the temperature leaching potential index (TLPI) depends on the water recharge $J_{\mathrm{w}}$ for specific site and hydrologic soil properties. We have estimated this values by the water balance approach using daily precipitation and evapotranspiration data, water irrigation data and the hydrologic group of the respective soil sample. Thus, for the soil properties given by Tables 2 and 3, the estimated value $J_{\mathrm{w}}$ was 0.0018 and $0.0021 \mathrm{~m} \mathrm{day}^{-1}$, respectively. Eq. (4), and the calculation procedures described by Hillel (1980) and Wu and Nofziger (1999), were used to determine the annual varia- tion of daily average soil temperature at different soil depths, as described in Tables 2 and 3. The minimal and maximal annual surface soil temperatures observed at a soil depth of $5 \mathrm{~cm}$ were $T_{\min }=15.3{ }^{\circ} \mathrm{C}$ and $T_{\max }=45.5$ ${ }^{\circ} \mathrm{C}$, respectively. The annual agronomic period of the herbicide applications and soil depth simulated was $t_{\mathrm{h}}=180$ days and $L=2 \mathrm{~m}$ (average depth of the vadose zone), respectively. This range of time horizon corresponds to the total of the $1600 \mathrm{~mm}$ annual precipitation in the São Gabriel do Oeste region. The numerical values of the TLPIs computed by Eq. (12) for all herbicides in the respective soil types (TONQ and TDRL) allows for classification into very low, low, moderate, high, and very high leachability classes. These results are summarized in Table 4 and suggest that a reasonable ranking of the groundwater potential herbicide contamination can be done considering the soil temperature effect. All the numeric results were accomplished by the mathematical scientific package MATLAB (1992).

Using TLPI equation a specific leachability class assigned to a particular herbicide varies with soil and herbicide properties. Monitoring data of herbicides atrazine, alachlor, metolachlor, simazine, and trifluraline in tropical soils of Brazil under field conditions,

Table 2

TONQ properties used for calculating the TLPI

\begin{tabular}{lllllllll}
\hline$\Delta L(\mathrm{~m})$ & $\begin{array}{l}\rho \\
\left(\mathrm{kg} \mathrm{m}^{-3}\right)\end{array}$ & $\begin{array}{l}\delta \\
(\%)\end{array}$ & $\begin{array}{l}\theta_{\mathrm{fc}} \\
(\%)\end{array}$ & $\begin{array}{l}f_{\mathrm{st}} \\
(\%)\end{array}$ & $\begin{array}{l}f_{\mathrm{cl}} \\
(\%)\end{array}$ & $\begin{array}{l}f_{\text {sd }} \\
(\%)\end{array}$ & $\begin{array}{l}f_{\mathrm{oc}} \\
(\%)\end{array}$ & $\begin{array}{l}\mathrm{SSA} \\
\left(\mathrm{m}^{2} \mathrm{~g}^{-1}\right)\end{array}$ \\
\hline $0.00-0.20$ & 1661.98 & 0.1702 & 0.1670 & 0.0336 & 0.1083 & 0.8581 & 0.0048 & 71.90 \\
$0.20-0.40$ & 1633.41 & 0.1944 & 0.1560 & 0.0195 & 0.1231 & 0.8574 & 0.0040 & 65.88 \\
$0.40-0.60$ & 1603.28 & 0.2125 & 0.1501 & 0.0108 & 0.1341 & 0.8551 & 0.0033 & 60.70 \\
$0.60-0.80$ & 1570.93 & 0.2241 & 0.1501 & 0.0083 & 0.1409 & 0.8508 & 0.0027 & 56.33 \\
$0.80-1.00$ & 1535.13 & 0.2282 & 0.1574 & 0.0135 & 0.1420 & 0.8445 & 0.0023 & 52.76 \\
$1.00-1.20$ & 1498.36 & 0.2267 & 0.1692 & 0.0234 & 0.1401 & 0.8366 & 0.0021 & 50.03 \\
$1.20-1.40$ & 1466.74 & 0.2244 & 0.1793 & 0.0304 & 0.1411 & 0.8284 & 0.0018 & 48.22 \\
$1.40-1.60$ & 1442.73 & 0.2232 & 0.1849 & 0.0317 & 0.1477 & 0.8206 & 0.0016 & 47.39 \\
$1.60-1.80$ & 1425.11 & 0.2221 & 0.1874 & 0.0287 & 0.1585 & 0.8128 & 0.0014 & 47.50 \\
$1.80-2.00$ & 1413.22 & 0.2208 & 0.1874 & 0.0221 & 0.1729 & 0.8050 & 0.0013 & 48.56 \\
\hline
\end{tabular}

Table 3

TDRL properties used for calculating the TLPI

\begin{tabular}{lllllllll}
\hline$\Delta L(\mathrm{~m})$ & $\begin{array}{l}\rho \\
\left(\mathrm{kg} \mathrm{m}^{-3}\right)\end{array}$ & $\begin{array}{l}\delta \\
(\%)\end{array}$ & $\begin{array}{l}\theta_{\mathrm{fc}} \\
(\%)\end{array}$ & $\begin{array}{l}f_{\mathrm{st}} \\
(\%)\end{array}$ & $\begin{array}{l}f_{\mathrm{cl}} \\
(\%)\end{array}$ & $\begin{array}{l}f_{\mathrm{sd}} \\
(\%)\end{array}$ & $\begin{array}{l}f_{\text {oc }} \\
(\%)\end{array}$ & $\begin{array}{l}\mathrm{SSA} \\
\left(\mathrm{m}^{2} \mathrm{~g}^{-1}\right)\end{array}$ \\
\hline $0.00-0.20$ & 1316.1480 & 0.1638 & 0.3147 & 0.1017 & 0.6400 & 0.2619 & 0.0167 & 298.08 \\
$0.20-0.40$ & 1315.8738 & 0.1795 & 0.3207 & 0.0825 & 0.6673 & 0.2502 & 0.0150 & 286.90 \\
$0.40-0.60$ & 1294.1792 & 0.1928 & 0.3278 & 0.0678 & 0.6922 & 0.2400 & 0.0134 & 275.28 \\
$0.60-0.80$ & 1246.6078 & 0.2038 & 0.3361 & 0.0577 & 0.7112 & 0.2311 & 0.0118 & 263.03 \\
$0.80-1.00$ & 1164.6649 & 0.2128 & 0.3463 & 0.0522 & 0.7239 & 0.2238 & 0.0103 & 249.83 \\
$1.00-1.20$ & 1065.3400 & 0.2193 & 0.3572 & 0.0513 & 0.7309 & 0.2178 & 0.0088 & 236.33 \\
$1.20-1.40$ & 990.6894 & 0.2227 & 0.3654 & 0.0540 & 0.7334 & 0.2127 & 0.0075 & 224.19 \\
$1.40-1.60$ & 957.7025 & 0.2226 & 0.3695 & 0.0601 & 0.7300 & 0.2082 & 0.0065 & 214.06 \\
$1.60-1.80$ & 957.8846 & 0.2191 & 0.3703 & 0.0697 & 0.7260 & 0.2044 & 0.0058 & 205.61 \\
$1.80-2.00$ & 986.7794 & 0.2125 & 0.3681 & 0.0829 & 0.7160 & 0.2015 & 0.0052 & 198.68 \\
\hline
\end{tabular}


Table 4

Herbicide-soil leachability class by TLPI results

\begin{tabular}{|c|c|c|c|c|}
\hline Herbicide & $\begin{array}{l}\text { TLPI in } \\
\text { TONQ }^{\mathrm{a}}\end{array}$ & $\begin{array}{l}\text { Leachability class } \\
\text { in TONQ }\end{array}$ & $\begin{array}{l}\text { TLPI in } \\
\text { TDRL }^{\mathrm{b}}\end{array}$ & $\begin{array}{l}\text { Leachability class } \\
\text { in TDRL }\end{array}$ \\
\hline $2,4-\mathrm{D}$ & 19 & Very low & 11 & Very low \\
\hline Acifluorfen-sodium & 15 & Very low & 8 & Very low \\
\hline Alachlor & 34 & Low & 7 & Very low \\
\hline Atrazine & 89 & High & 47 & Low \\
\hline Bentazone & 33 & Low & 19 & Low \\
\hline Butroxydim & 14 & Very low & 8 & Very low \\
\hline Chlorimuron-ethyl & 44 & Low & 23 & Very low \\
\hline Clomazone & 18 & Very low & 9 & Very low \\
\hline Cyanazine & 11 & Very low & 6 & Very low \\
\hline Diclosulam & 129 & Very high & 80 & High \\
\hline Dimethenamid & 51 & Moderate & 27 & Low \\
\hline Diquat & 0 & Very low & 0 & Very low \\
\hline Fenoxaprop & 13 & Very low & 6 & Very low \\
\hline Fluazifop-p-butyl & 1 & Very low & 0 & Very low \\
\hline Flumetsulam & 129 & Very high & 83 & High \\
\hline Flumiclorac-pentyl & 0 & Very low & 0 & Very low \\
\hline Fomesafen & 142 & Very high & 79 & High \\
\hline Haloxyfop & 72 & Moderate & 39 & Low \\
\hline Imazaquin & 111 & Very high & 67 & Moderate \\
\hline Imazethapyr & 181 & Very high & 112 & Very high \\
\hline Lactofen & 0 & Very low & 0 & Very low \\
\hline Linuron & 30 & Low & 14 & Very low \\
\hline Metolachlor & 72 & Moderate & 36 & Low \\
\hline Metribuzin & 57 & Moderate & 31 & Low \\
\hline Paraquat & 0 & Very low & 0 & Very low \\
\hline Pendimethalin & 5 & Very low & 2 & Very low \\
\hline Picloram & 2 & Very low & 1 & Very low \\
\hline Sethoxydim & 6 & Very low & 3 & Very low \\
\hline Simazine & 71 & Moderate & 38 & Low \\
\hline Sulfentrazone & 856 & Very high & 488 & Very high \\
\hline Trifluralin & 2 & Very low & 1 & Very low \\
\hline
\end{tabular}

${ }^{\text {a }}$ Typic Orthic Neosol Quartzarenic.

${ }^{\mathrm{b}}$ Typic Distrophic Red Latossol.

published by Laabs et al. (2002), Laabs et al. (2000), and of the herbicide atrazine by Cerdeira et al. (1998), corroborate the temperature leaching potential indexes presented in Table 4. The dependency of TLPI on the soil temperature and the lower half-life at high temperatures can be explained by the fact that most herbicides are associated with very high groundwater contamination potentials, but show low to moderate leaching potentials in tropical regions, despite the fact that pesticide degradation rates are positively related to soil temperature. It is universally accepted that the three most important characteristics of a pesticide, that influence their leaching potential to the groundwater, are: high aqueous solubility, low soil sorption, and high persistence in the soil matrix. Observing the herbicide characteristics in Table 1, and the results presented in Table 4, there are no contradictions to this general statement. The TLPI index is a numerical value that indicates the susceptibility of groundwater to herbicide contamination. For example, the TLPI scoring for atrazine are 89 and 47, in the TONQ and TDRL soils, respectively. Based on these scores, the respective relative atrazine mass at a depth of $2 \mathrm{~m}$ to groundwater is estimated $1.3 \mathrm{E}-03$ percent and $5.75 \mathrm{E}-08$ percent of the applied mass after 180 days. In other words, the TLPI estimates that there will be $2.29 \mathrm{E}+4$ times more atrazine in the TONQ soil than in the TDRL soil, with potential leaching into the groundwater. Thus, the results of Table 4 indicate the herbicides that should have priority in a monitoring program of groundwater herbicide contamination.

\section{Conclusions}

The problems associated with the assessment of nonpoint source groundwater contamination by herbicides in tropical soils were addressed. The results 
presented in Table 4 can be useful in other areas and the method to calculate the TLPI index can be used to refine pesticide leaching potential assessments in temperate climatic conditions, as demanded by Brücher and Bergström (1997). Application of the TLPI associated with spatial analysis and GIS can be useful in evaluating groundwater contamination potential of a large number of pesticides applied to a large area quickly and economically, and to inform decision makers in a more effective manner. Results of sensitivity analysis of the TLPI can be used to show that groundwater pesticide contamination depends on hydrological, pesticides and soil properties, and climatic conditions. However, soil characteristics, pesticides properties and climatic conditions appeared to be key factors in evaluating vulnerability in a hypothetical hydrological setting. Efforts have been made to evaluate herbicides leaching potential under field soil and climatic conditions, where abundant groundwater supplies occur in shallow, unconfined aquifers, and crop fields are intensively managed with herbicide applications.

Result have shown that the TLPI is a useful tool in classifying susceptible areas to groundwater degradation by herbicides and to indicate the priority herbicides to be assessed by monitoring programs. The thermodynamic parameters necessary to calculate the TLPI, activation energy, volatilization, and sorption enthalpy, depend not only on the pesticide-water-soil system, but also on the conditions under which the analyses are made. The temperature effect on sorption depends on the energy transfer during the sorption process, and an inverse relationship dependence has been found for a large number of nonionic organic chemical compounds (Chiou et al., 1979). The van't Hoff equation can be applied to estimate the pesticide partition coefficient in order to determine the retardation factor as a function of soil temperature. The choice of herbicide is most critical for farmers on vulnerable soil and water resources. This is a complex task that must take into account the crop, the tillage system, target species, and other important environmental factors. Physical and chemical properties of the herbicides must be considered when evaluating their leaching potential to the groundwater.

The inclusion of soil temperature in the LPI proved to be important and essential to estimate the leaching potential of the herbicides studied in tropical conditions. Van Duin (1956) has shown that the magnitude of temperature variation at the soil surface is greater in tilled than in untilled soils, and that this amplitude decreases with depth more steeply in tilled than untilled soil. It was also found that tilled soil could be warmer at surface but cooler below a certain depth, what enhance, the addition of temperature effect in our proposed temperature leaching potential index.

\section{Acknowledgements}

Project funded by PRODETAB 'Projeto de Apoio ao Desenvolvimento de Tecnologia Agropecuária para o Brasil' under the 'S.O.S. Taquarí Project', grant number 093/01-98. We thank Dr Manoel Dornelas de Souza for technical assistance in soil physics, Mrs Luiza Costa Mota Paraíba for her linguistic advice, Mr Sérgio Ponce for field assistance, and the São Gabriel do Oeste municipality for their logistic support.

\section{References}

Bacci, E., 1994. Ecotoxicology of Organic Contaminants. CRC Press, Inc., Boca Raton, FL.

Baer, U., Calvet, R., 1999. Fate of soil applied herbicides: experimental data and prediction of dissipation kinetics. J. Environ. Qual. 28, 1765-1777.

Bari, M.F., Anwar, A.H.M.F., 1998. Groundwater vulnerability to pesticide leaching and prioritizing monitoring sites in north-west Bangladesh. In: Wheater, H., Kirby, C. (Eds.), Hydrology in a Changing Environment. Vol. II. Bangladesh University of Engineering and Technology, Dhaka, Bangladesh. Proceedings of the British Hydrological Society International Conference, Exeter, UK, July 1998. John Wiley \& Sons Ltd., Chichester, UK, pp. 77-88.

Boesten, J.J.T.I., 2000. From laboratory to field: uses and limitations of pesticide behaviour models for the soil/plant system. Weed Res. 40, 123-138.

Bouwer, H., 1990. Agricultural chemicals and ground water quality. J. Soil Water Conserv. 42, 184-189.

Brücher, J., Bergström, L., 1997. Temperature dependence of linuron sorption to three different agricultural soils. J. Environ. Qual. 26, 1327-1335.

Campbell, G.S., 1985. Soil Physics with Basic: Transport Models for Soil-Plant Systems. Elsevier, New York.

Cerdeira, A.L., Lanchote, V.L., Queiroz, R.C., Bonato, P.S., Gomes, M.A., Shuhama, I., Ueta, J., 1998. Herbicides residues in soil and water from sugarcane area in Brazil. In: World Congress of Soil Science, 1998, Montpellier, France. Proceedings, ISSS, International Soil Science Society. CIRAD, Paris.

Chiou, C.T., Peters, L.J., Freed, V.H., 1979. A physical concept of soil-water equilibria for nonionic organic compounds. Science 206, 831-832.

Goedert, W.J., 1983. Management of Cerrado soils of Brazil: a review. J. Soil Sci. 34, 405-428.

Goss, K.U., Schwarzenbach, R.P., 1999. Empirical prediction of heats of vaporization and heats of adsorption of organic compounds. Environ. Sci. Technol. 33, 3390-3393.

Gustafson, D.I., 1994. New advances in predicting pesticide fate and transport. In: Copin, A., Houins, G., Pussemier, L., Salembier, J.F. (Eds.), Environmental Behaviour of Pesticides and Regulatory Aspects. European Study Service, Rixensart, Belgique, pp. 453-458.

Gómez de Barreda, D., 1999. Comportamiento de herbicidas residuales en suelo: posible contaminación de acuiferos. Tesis Doctoral. Universidad Politécnica de Valencia, Sphain. 
Hillel, D., 1980. Fundamentals of Soil Physics. Academic Press, Inc., London, UK.

Hillel, D., 1982. Introduction to Soil Physics. Academic Press, Inc., San Diego, CA.

Hornsby, A.G., Don Wauchope, R., Herner, A.E., 1996. Pesticide Properties in the Environment. Springer-Verlag, Inc., New York, NY.

Hulscher, ten, Th.E.M., Cornelissen, G., 1996. Effect of temperature on sorption equilibrium and sorption kinetics of organic micropollutants - a review. Chemosphere 32 (4), 609-629.

Jury, W.A., Gardner, W.R., Gardner, W.H., 1992. Soil Physics. John Wiley \& Sons, Inc., New York.

Kavanaugh, M.C., Trussel, R.R., 1980. Design of aeration towers to strip volatile contaminants from drink water. J. Am. Water Works Assoc. 72 (12), 684-692.

Keen, R.E., Spain, J.D., 1992. Computer Simulation in Biology: A Basic Introduction. Wiley-Liss, Inc., New York.

Laabs, V., Amelung, W., Pinto, A., Altstaedt, A., Zech, W., 2002. Fate of pesticides in tropical soils of Brazil under field conditions. J. Environ. Qual. 31, 256-268.

Laabs, V., Amelung, W., Pinto, A., Altstaedt, A., Zech, W., 2000. Leaching and degradation and soybean pesticides in an Oxisol of the Brazilian Cerrados. Chemosphere 41, 14411449.

MATLAB, 1992. The Student Edition of MATLAB. MathWorks, Inc., Prentice Hall, Englewood Cliffs, NJ.

Meeks, Y.J., Dean, J.D., 1990. Evaluating groundwater vulnerability to pesticides. J. Water Resour. Plng. Mgmt. 116, 693-707.

Nirmalakhandan, N., Brennan, R.A., Speece, R.E., 1997. Predicting Henry's law constant and effect of temperature on Henry's law constant. Water Res. 31 (6), 1471-1481.

Oliveira Jr., R.S., Koskinen, W.C., Ferreira, F.A., 2001. Sorption and leaching potential of herbicides on Brazilian soils. Weed Res. 41, 97-110.

Paraíba, L.C., Spadotto, C.A., 2002. Soil temperature effect in calculating attenuation and retardation factors. Chemosphere 48, 905-912.

Pickus, J., Hewitt, M., 1992. Resource at risk: analyzing sensitivity of groundwater to pesticides. Geo. Info. Syst. 2 (10), 50-55.

Pionke, H.B., De Angelis, R.J., 1972. Method for distributing pesticide loss in field runoff between the solution and adsorbed phase. In: CREAMS, a Field Scale Model for Chemicals, Runoff, and Erosion from Agricultural Management Systems, USDA Conservation Res. Rep. 26, USDA, SEA, Washington, DC, pp. 607-645.

Rao, P.S.C., Hornsby, A.G., Jessup, R.E., 1985. Indices for ranking the potential for pesticide contamination of groundwater. Proc. Soil Crop Sci. Soc. Fla. 44, 1-8.

Rattanagreetakul, C., Korpraditskul, R., Korpraditskul, V., 1991. Effect of temperature and soil moisture on atrazine degradation. Kasetsart J. (Nat. Sci. Suppl.) 25, 75-79.
Resck, D.V., 1998. Agricultural intensification systems and their impact on soil and water quality in the Cerrados of Brazil. In: Lal, R. (Ed.), Soil Quality and Agricultural Sustainability. Ann Arbor Press, Chelsea, pp. 288-300.

Rice, C.P., Chernyak, S.M., McConnell, L.L., 1997. Henry's law constants for pesticides measured as a function of temperature and salinity. J. Agric. Food Chem. 45, 22912298.

Rocha, F., Walker, A., 1995. Simulation of the persistence of atrazine in soil at different sites in Portugal. Weed Res. 35, 179-186.

Sagebiel, J.C., Seiber, J.N., Woodrow, J.E., 1992. Comparison of headspace and gas-stripping methods for determining the Henry's law constant $(H)$ for organic compounds of low to intermediate $H$. Chemosphere 25 (12), 1763-1768.

Sattin, M., Berti, A., Zanin, G., 1995. Agronomic aspects of herbicide use. In: Vigh, M., Funari, E. (Eds.), Pesticide Risk in Groundwater. CRC Press, Inc., Lewis Publishers, Boca Raton, FL, pp. 45-70.

USDA, 1999. Soil survey staff. Soil Taxonomy: A Basic System of Soil Classification for Making and Interpreting Soil Surveys, second ed. Washington, US Govt. Printing Office, 869 p. (US Department of Agriculture Handbook, p. 436).

Schlosser, S.A., McCray, J.E., 2002. Sensitivity of a pesticide leaching-potential index model to variations in hydrologic and pesticide-transport properties. Environ. Geosci. 9 (2), 66-73.

Schlosser, S.A., McCray, J.E., Murray, K.E., Brad, A., 2002. A subregional-scale method to assess aquifer vulnerability to pesticides. Ground Water 40 (4), 361-367.

Schwarzenbach, R.P., Gschwend, P.M., Imboden, D.M., 1993. Environmental Organic Chemistry. John Wiley \& Sons, Inc., New York.

Tomlin, C.D.S., 2000. The Pesticide Manual. British Crop Protection Council, Farnham, UK.

Van Duin, R.H.A., 1956. On the Influence of Tillage on Conduction of Heat Diffusion of Air, and Infiltration of Water in Soil. Versl. Landbouwk, Onderz. p. 62.

Veeh, R.H., Inskeep, W.P., Camper, A.K., 1996. Soil depth and temperature effects on microbial degradation of 2,4-D. J. Environ. Qual. 25, 5-12.

Walker, A., 1974. A simulation model for prediction of herbicide persistence. J. Environ. Qual. 4, 396-401.

Walker, A., Barnes, A., 1981. Simulation of herbicides persistence in soil: a revised computer model. Pest. Sci. 12, 123132.

Williams, W.M., Holden, P.W., Parsons, D.W., Lorber, M.N., (1988). Pesticides in Ground Water Database, Interim Report. US Environmental Protection Agency, Washington, DC.

Wu, J., Nofziger, D.L., 1999. Incorporating temperature effects on pesticide degradation into a management model. J. Environ. Qual. 28, 92-100. 